\title{
Detecting Evidence of Guilt in the Communicative Behavior of Preschool-Aged Children. How Preschool Teachers could be in Forensic Scientists' Shoes?
}

\author{
Panagiotis J Stamatis* \\ Department of Sciences of Preschool Education and Educational Design, Greece \\ *Corresponding author: Panagiotis J Stamatis, Department of Sciences of Preschool Education and Educational Design, Greece \\ Submission: 海February 26, 2018; Published: 望 February 27, 2018
}

\section{Opinion}

Have you ever noticed what preschool children say and how they react when the teacher, the parents or any other adult person asks them why they committed a violent act against somebody else (child or another person) or against an object? In other words, have you ever observed how preschool kids react when somebody "interrogates" them, reprimand them or blame them because they perpetrated an infringing behavior? How do they express themselves when someone asks them to apologize, ascribing the responsibility to them for misconduct or demonstrating their guilt for an "evil" act? How could an early childhood educator verify if a preschooler, who is blamed by another child to be guilty for something bad that has happened in the kindergarten setting, is actually responsible or not for anything that s/he has been accused of? It is widely known that preschool teachers have not been educated in the detection of truth or children's falsehood, they are neither detectives nor judges, even though they are frequently asked to collect evidence in order to effectively practice the role that informally has been assigned to them by the state and is integrated in the kit of their many and various duties [1,2]. In all these questions, it is intended to be given some answers that are based on long educational experience and in my opinion.

Usually, in such cases, as observed in the everyday school practice, early childhood teachers do not have an alternative, in a way, but using similar techniques as those utilized by forensic scientists, which investigate thoroughly the crime scene to compile as much evidence as possible that will lead to the crime solving [3,4]. Certainly, when "criminal actions" are performed by preschoolers, instead of investigating any scene or material, it is adequate for the early childhood educators to focus their attention on the investigation of the verbal expressions that preschool children use and the signals that are emanated by their body language during the "interrogation" phase, that is when teachers ask children to give answers to questions like "George, why did you hurt Maria?" or "Why did you break the window?" [5].

An experienced early childhood teacher could observe that when a preschool child is asked to "apologize", most probably, in the beginning $s /$ he refuses to say anything, $s /$ he willfully refuses to speak [6]. Usually, s/he stands up or sits down somewhere in the classroom, folds his/her arms taking a defensive position, bows his/ her head, glances down, purses her/his lips and generally shows anger in his/her face, whereas s/he refuses to answer teacher's questions, especially when his/her voice is strong and her/his tone is critical. Finally, the preschooler responds after a few minutes and usually when the teacher has already repeated the question a couple of times, calming him/her down at the same time, using a kind look and a mild voice tone that his/her answer will not affect negatively their relationship or be given a punishment, even if s/he has committed something really bad. Consequently, the preschool child especially if $\mathrm{s} /$ he is or feels guilty, gains courage to respond only if $s /$ he receives the requisite guarantees for the lenient attitude towards him/her and his/her protection. If the child is not guilty, then s/he can immediately refuse his/her guilt without cries, blaming another child that names, using a plaintive voice or bursting into tears, because s/he feels deprived. Such reaction of a preschooler is usually honest, because children of that age have not learned yet how to pretend or feign in order to hypocritically abdicate the guilt, misleading the teacher $[7,8]$. It is common enough for older children to strongly protest and tell lies in order to persuade others for their innocence, exactly as adults frequently do by incriminating other people instead of themselves [9].

Referring always to normal early childhood kids, we all know that the way of handling an accusation against them, differs from preschooler to preschooler, because a variety of factors and especially the experiences that each of them has received from his/ 
her family and widely social environment influence that way, as well as her/his overall behavior $[10,11]$. Moreover, the communicative skill and the possibilities of expressing thoughts and feelings that every preschool child possesses, create different reaction responses to an indictment against him/her either in case s/he is aware and pleads guilty or in case s/he considers normal or rightful his/her infringing conduct and as a result completely justifiable, thus s/he does not feel guilty [12].

In the nursery setting, it is noted that some preschool children are more or less tolerant or prone to violence, lying, aggression in general, some have more or less developed their perceptional and communicative skill, and some possess more social skills than others. It is responsibility of both the educational and family environment, after they have systematically diagnosed these differences, as well as the strengths and weaknesses of the conduct of each child, to take care of their immediate support where needed through the educational process, the cooperation and the frequent communication between early childhood teachers and parents, by carrying out together actions and activities with ultimate goal the avoidance of conflicts, in order to prevent the incrimination of the child, aiming at the elimination of being accused and then apologizing for infringing actions or oversights [13,14]. However, if the preschooler finds himself/herself in such a position, s/he should have the ability and courage to frankly explain the real events, so that the problem be solved in a peaceful and rightful way.

As the exhibits of a crime that are collected by forensic scientists, even though sufficient, do not always lead to its definite solving, also the detection and interpretation of the verbal expressions and nonverbal signs of guilt that preschool children use, in cases they are accused of committing infringing behaviors, cannot always lead teachers to the objective reality by verifying utterly the guilt or innocence of a preschooler that is being indicted. However, they can result in reaching with great success close to the truth. Additionally, early childhood educators could be immensely helped by their educational experience, their perceptual and intuitive ability, their adequate knowledge of the behavior of each preschooler, their investigative mood and the proper handling of every incidence without any prejudices.

\section{References}

1. Nelsen J, Lott L, Glenn HS (2013) Positive discipline in the classroom: Developing mutual respect, cooperation, and responsibility in your classroom, Harmony, USA

2. Canter L (2009) Assertive discipline: Positive behavior management for today's classroom. Solution Tree, USA.

3. Saferstein R (2015) Forensic science. From the crime scene to the crime lab. Pearson, UK.

4. James SH, Nordby JJ, Bell S (2014) Forensic science: An introduction to scientific and investigative techniques. FL: Taylor \& Francis Group, LLC, Boca Raton, UK.

5. Stamatis PJ, Papavasileiou V, Ntouka A (2013) Detecting emotions by observing nonverbal behaviors of preschoolers during narration and movie presentation of a fairy tale. The International Journal of Early Childhood Learning 20(1): 13-22.

6. Stamatis PI (2017) Communication violence in verbal expression and nonverbal behavior of preschool and early primary school teachers during teaching process: An observational study. International Journal of Criminology and Sociology 6: 159-165.

7. Adams L (2016) Passive aggressive: How to spot and manage passive aggressive people. Create Space Independent Publishing Platform, LLC, UK.

8. Brandt A, Rothschild B (2013) 8 keys to eliminating passive-aggressive, W. W. Norton \& Company, New York, USA.

9. Alvarez AC, Bachman RD (2017) Violence: The enduring problem. SAGE Publications, Inc, India.

10. Oren C (2015) Passive aggressive behavior: How to deal with passive aggressive people. White Owl Publishing, Miami, FL, USA.

11. Scott TM, Park KL, Bradway SJ, Landers E (2007) Positive behavior support in the classroom: facilitating behaviorally inclusive learning environments. International Journal of Behaviorial Consultation and Therapy 3(2): 223-235.

12. Simonds CJ, Cooper PJ (2011) Communication for the classroom teacher. ( $9^{\text {th }}$ edn.), Pearson Education, Inc, USA

13. Stamatis PJ, Nikolaou E (2017) Communication and Collaboration between school and family for addressing bullying. International Journal of Criminology and Sociology 5: 99-104.

14. White KW (2016) Teacher communication: A guide to relational, organizational and classroom communication. Rowman \& Littlefield Publishers, Maryland, USA.
Your subsequent submission with Crimson Publishers will attain the below benefits

- High-level peer review and editorial services

- Freely accessible online immediately upon publication

- Authors retain the copyright to their work

- Licensing it under a Creative Commons license

- Visibility through different online platforms

- Global attainment for your research

- Article availability in different formats (Pdf, E-pub, Full Text)

Endless customer service

- Reasonable Membership services

- Reprints availability upon request

One step article tracking system 